IZA DP No. 6656

Maternal Gender Role Attitudes, Human Capital Investment, and Labour Supply of Sons and Daughters

David W. Johnston

Stefanie Schurer

Michael A. Shields

June 2012 


\title{
Maternal Gender Role Attitudes, Human Capital Investment, and Labour Supply of Sons and Daughters
}

\author{
David W. Johnston \\ Monash University \\ Stefanie Schurer \\ Victoria University of Wellington \\ and IZA \\ Michael A. Shields \\ University of Melbourne \\ and IZA
}
Discussion Paper No. 6656
June 2012

IZA

P.O. Box 7240

53072 Bonn

Germany

Phone: +49-228-3894-0

Fax: +49-228-3894-180

E-mail: iza@iza.org

\begin{abstract}
Any opinions expressed here are those of the author(s) and not those of IZA. Research published in this series may include views on policy, but the institute itself takes no institutional policy positions.

The Institute for the Study of Labor (IZA) in Bonn is a local and virtual international research center and a place of communication between science, politics and business. IZA is an independent nonprofit organization supported by Deutsche Post Foundation. The center is associated with the University of Bonn and offers a stimulating research environment through its international network, workshops and conferences, data service, project support, research visits and doctoral program. IZA engages in (i) original and internationally competitive research in all fields of labor economics, (ii) development of policy concepts, and (iii) dissemination of research results and concepts to the interested public.
\end{abstract}

IZA Discussion Papers often represent preliminary work and are circulated to encourage discussion. Citation of such a paper should account for its provisional character. A revised version may be available directly from the author. 


\begin{abstract}

\section{Maternal Gender Role Attitudes, Human Capital Investment, and Labour Supply of Sons and Daughters}

Using data from the 1970 British Cohort Study, we investigate the role of maternal gender role attitudes in explaining the differential educational expectations mothers have for their daughters and sons, and consequently their children's later educational outcomes and labour supply. We find that mothers' and children's gender role attitudes, measured some 25 years apart, are significantly correlated, equally so for sons and daughters. Moreover, daughters are significantly more likely to continue school beyond the minimum school-leaving age, participate in the labour force, and work more hours, if their mothers held non-traditional (progender-equality) beliefs, even if they were not working themselves. Consistent with the hypothesis that maternal gender role attitudes affect daughters' economic opportunities only, we find no effect on sons' education outcomes and labour supply. However, we find that mothers' attitudes are significantly correlated with sons' partners' (daughter-in-law) labour supply. All these results suggest that the intergenerational transmission of non-traditional attitudes from mothers to their children explain a substantive part of gender inequalities in economic opportunities, and that attitudes and outcomes persevere across generations through assortative mating.
\end{abstract}

JEL Classification: $\quad$ J62

Keywords: maternal gender role attitudes, intergenerational transmission, labour supply, human capital investment, expectations, cohort data

Corresponding author:

Stefanie Schurer

School of Economics and Finance

Victoria University of Wellington

Rutherford House, Level 3

23 Lambton Quay

Wellington 6041

New Zealand

E-mail: stefanie.schurer@vuw.ac.nz 


\section{Introduction}

One of the central questions in the social sciences is why some people are 'successful' in life, while others are not. Success in life is not uniquely defined - its definition differs between cultures and changes over time - but a vast literature has traditionally focused on success in terms of economic outcomes such as educational attainment, occupation, wages and income. Economists have contributed strongly to this literature, with an emphasis on establishing the importance of the childhood socioeconomic environment in explaining economic inequalities in adulthood. An integral part of this literature are the studies that attempt to quantify the extent to which parent and child outcomes in life are correlated (e.g. Haveman and Wolfe, 1995; Solon, 1999; and Black and Devereux, 2011, for reviews).

The socioeconomic environment in which children are raised, traditionally measured by parental education, social class and household income, has been shown many times to be a significant predictor of children's educational attainment, occupational attainment, wages, family income, health and longevity. For example, estimates of the intergenerational correlation in wages typically range between 0.2 and 0.6 , although such estimates are sensitive to when in the lifecycle the wages of parents and children are measured (e.g. Dearden et al., 1997; Solon, 1999; Mazumder, 2005; Black and Devereux, 2011). Recent years have seen a wide expansion in the scope of this literature, with studies documenting intergenerational correlations in IQ, welfare receipt, consumption, expenditure, savings, health and health-related behaviours, personality traits, and other non-cognitive skills and social behaviour (see Black and Devereux, 2011). A clear motivation of this research is to better understand the determinants and dynamics of intergenerational correlations in economic outcomes, and the extent of intergenerational mobility within a society. Knowledge of the determinants of social mobility is important for the design of policies aimed at reducing societal inequalities.

An influential component of the recent intergenerational mobility literature is a number of studies demonstrating that beliefs, preferences and attitudes are important pathways through which economic outcomes between parents and children are correlated (e.g. Guiso et al., 2006, 2008; Fernández et al., 2004; Fernández and Fogli, 2009). For example, Dohmen et al. (2011) illustrate empirically with German longitudinal data how attitudes towards risk and trust are passed on from parents to children, and how these two attitudes shape the child's economic situation. They note that, "by passing on their risk and trust attitudes, parents fundamentally change the child's whole disposition towards economic decision making, with important ramifications for the child's overall economic situation" (p. 12).

Similar ideas of endogenous transmission of attitudes have been expressed in theoretical work. Bisin and Verdier $(2000,2001)$ model the optimal amount of cultural transmission of values by 
altruistic, but paternalistic parents, to maximise their children's future utility. Hauk and Saez-Marti (2002) model the intergenerational transmission of ethical values in the presence of economic incentives and discuss the various consequences on the level of corruption in society. Doepke and Ziliboti (2008) model the transmission of patience between parents and their children and its influence on choices of occupation and lifetime consumption patterns. Baron et al. (2008) model the intergenerational transmission of attitudes towards work and welfare receipt.

Many aspects of the intergenerational transmission of outcomes have been well studied; however, relatively few studies have empirically investigated the importance of gender role attitudes, and their impact on human capital formation and labour supply of women. Gender role attitudes are the beliefs individuals hold regarding the role women should fulfil in society, and thus both reflect and determine the level of gender equality within a population. Parents who believe that a woman's place is at home are likely to make fewer human capital investments in their daughters than parents who do not, which will in-turn affect their daughters adult economic opportunities, as well as their choices of whether and when to marry, and when and how many children to have. Some evidence in the literature shows large effects of gender role attitudes on daughter's educational attainment (Vella, 1994), labour supply (Levine, 1993; Fortin, 2005) and fertility decisions (Fernández and Fogli, 2009). Moreover, it is found that a significant portion of the large variation observed across time in female labour supply can be explained by variation in gender role attitudes (Fortin, 2009).

Whether gender role attitudes are passed on from parents to children in a similar way and magnitude as economic outcomes is not yet clear, as few economic studies quantify the intergenerational correlation. The difficulty in identifying the intergenerational correlation lies in the scarcity of data that provides information on both parents' and children's attitudes measured in the correct sequence. An exception is Farré and Vella (2007), who found an intergenerational correlation of gender role attitudes (using data from the NLSY79) of around 0.09, where mothers' and children's attitudes are recorded in 1979 and 1998/2000, respectively. Another exception is Moen et al. (1997), who found using data from a small New York study that mother's gender role ideology recorded in the 1950s is positively related to their daughters' gender role ideology, with a significant intergenerational correlation coefficient ranging between 0.098 and 0.12 .

It is however not only parental gender role attitudes that are important, but also the attitudes that husbands hold, as they may influence their wives' labour supply decisions. A study by Fernández et al. (2004) hypothesises that men whose mothers worked when they were adolescents, develop a preference over working wives, or are raised in a way that promotes helping out more in the household, making it easier for their wives to work. Consequentially, these husbands should be more likely to have wives who work outside the household. Analysing data from the US they find 
that having a working mother increased the probability that a man's spouse worked by 32 percentage points (from 39\% to 71\%). Kawaguchi and Miyazaki (2009) find that Japanese men whose mothers' worked when they were aged 15 are more likely to have working wives, and also that they are more likely to develop modern views about gender roles. Similar results are reported in Farré and Vella (2007).

In this paper we contribute to the understanding of the mechanisms that link parental and child labour market outcomes by documenting the importance of maternal attitudes towards gender equality in the labour market (what they say), and the importance of maternal work status (what they do), in explaining adult labour force participation decisions of particularly daughters, but also of sons and daughters-in-law. One potential pathway through which non-traditional maternal gender role attitudes can affect daughters' future labour supply is by increasing the probability of higher educational achievement. It is reasonable to think that a non-traditional mother might devote more time and/or resources to her daughter's education, relative to a mother who holds a more traditional belief about a woman's role in society. In contrast, we might expect to find a much weaker relationship between mothers' work attitudes and sons' educational attainment. We also investigate if maternal gender role attitudes are predictive of the labour supply of daughters-in-law, which informs on the process of assortative mating based on work preferences.

To test these hypotheses we use data from the British Cohort Study (BCS) which has tracked children born in Britain in April 1970 until 2008 (age 38). Maternal attitudes towards women's role in the workforce, and the own work status of mothers, are both measured in 1975 when the cohort child was aged 5. In addition, in 1980 (at age 10) mothers were asked what level of education they expected their child to achieve. We then follow these children into adulthood to see what gender role attitudes they hold at age 30, what education level they attained (by age 34), and whether they participate in the labour market and how many hours they work (age 30, 34 and 38).

The early measurement of maternal attitudes coupled with detailed information on socioeconomic conditions during cohort members' childhood is a key advantage of the BCS data, as it allows us to separate the effects of attitudes on future outcomes from the confounding effects of economic factors. Other advantages of the BCS data are the measurement of economic outcomes of cohort members and their mothers at similar stages in the lifecycle (around aged 30), and the capacity to control for cohort member cognitive ability (age 5), which is known to be strongly correlated with attitudes and economic success (Dohmen et al., 2010). Moreover we are able to control for general parenting style (ranging liberal to authoritarian), which is found to be correlated with maternal gender role attitudes, and importantly we are able to use disaggregated geographical identifiers to separate the effect of maternal attitudes from the effect of prevailing attitudes within the family's neighbourhood. 


\section{Data and Descriptive Statistics}

\subsection{The 1970 British Cohort Study}

The data we use are drawn from the 1970 British Cohort Study (BCS70). The BCS70 was initiated by the National Birthday Trust Fund and the Royal College of Obstetricians and Gynaecologists, and began with an at-birth survey of around 17,000 people born between April 5-11 1970 in England, Scotland, Wales and Northern Ireland (overall catchment was estimated at 95 to 98 percent of all births). Originally designed to study perinatal mortality and the provision of ante- and post-natal services (Chamberlain, 1975), the BCS70 was subsequently expanded and now includes seven major follow-up surveys: 1975, 1980, 1986, 1996, 2000, 2004 and 2008. The three major childhood surveys (age 5,10 and 16) include, in addition to the original birth cohort, any children who were born outside of the country during the reference week but who were identified from school registers at later ages. These childhood surveys collected detailed information from parents (mostly the child's mother) on the cohort member's health and behaviour, and on family demographics and socioeconomic status. Cognitive ability was also assessed in these surveys via a range of tests administered by the survey interviewers. The four major adult surveys collected information from the cohort member on employment, income, education, health, relationships and attitudes.

Our analysis is primarily based upon data from the 1975, 1980, 2000, 2004 and 2008 surveys. The 1975 survey contains an attitudes questionnaire given to mothers, the 1980 survey contains information on mothers' education expectations for their children, and the 2000-2008 surveys contain information on cohort-member educational attainment and labour market outcomes (employment status, weekly hours worked). The 2000 survey also contains information on cohortmember attitudes. The estimation sample is restricted to those cohort-members who have nonmissing information on maternal attitudes and employment from 1975, own attitudes from 2000, and own employment status from one of 2000, 2004 and 2008 (not necessarily from all three). These restrictions leave us with an estimation sample of 8,683 cohort members, including 4,464 daughters and 4,219 sons, and 3,343 daughters-in-law (partnered sons).

\subsection{Measuring gender role attitudes}

In 1975 only, when the cohort members were aged 5, mothers were given an attitudes questionnaire that included the following seven statements related to gender roles:

(1) Women need something more from life than they can get by just looking after the home and children. 
(2) Girls should accept the fact that they will marry and have children and not think about starting a career.

(3) Women should have the same work opportunities as men.

(4) There is nothing wrong with a mother going out to work if her children can be properly cared for by someone else.

(5) A mother who leaves her children with someone else in order to go out to work is no fit to be a mother unless she needs the money for food and clothes.

(6) A wife must sacrifice her right to go out to work once she has children.

(7) A mother's proper place is at home with her children.

The mothers could answer each question with one of: strongly disagree (1), mildly disagree (2), cannot say (3), mildly agree (4), and strongly agree (5). The proportions answering (1) to (5) for each statement are given in Appendix Table A1. We form an index of maternal gender role attitudes by averaging answers (some reverse coded) and standardising such that the index is bound between 0 (traditional) and 1 (non-traditional). ${ }^{1}$ Mothers with an index score of zero answered strongly disagree to questions (1), (3) and (4), and answered strongly agree to questions (2), (5), (6) and (7). The reverse is true for mothers with an index score of one. A one-unit increase in the index is thus interpreted as moving from very traditional gender role attitudes (or anti-maternal-employment) to very non-traditional gender role attitudes (or pro-maternal-employment). ${ }^{2}$

Figure 1 presents kernel density estimates of maternal gender role attitudes by maternal employment status (also measured in 1975). Unsurprisingly, there is a positive association between the index and hours worked - part-time employed mothers have less-traditional views than nonworking mothers, and full-time employed mothers have less traditional views than part-time employed mothers. The shapes of the distributions also differ by maternal employment status. The index of non-working mothers is almost normally distributed, whereas the distributions for working mothers are more negatively skewed. In other words, most working mothers are pro-maternal employment, though there are working mothers in the sample who believe that mothers should not work. Specifically, $21 \%$ of non-working mothers score less than 0.5 (i.e. traditional), compared with $9 \%$ of part-time employed mothers and $4 \%$ of full-time employed mothers.

The cohort member's own gender role attitudes are measured in the 2000 survey. The cohort member was then 30 years of age, and therefore is at a similar lifecycle stage as his or her mother in

\footnotetext{
${ }^{1}$ The results using this approach are almost identical to those using an index constructed from the predicted first factor from a principal components factor analysis. These results are available upon request.

${ }^{2}$ There exists no single instrument to elicit gender role preferences; however, some of the statements used here, in slightly modified versions, have been used in other studies. For examples, see Farré and Vella (2009), Vella (1994), Levine (1993), Powell et al. (1982), Moen et al. (1997), and Thornton et al. (1979).
} 
1975 (average age of mothers in 1975 is 31). The 2000 survey included the following five statements related to gender roles:

(1) A pre-school child is likely to suffer if his or her mother works.

(2) All in all, family life suffers when the mother has a full time job.

(3) Children benefit if their mother has a job outside the home.

(4) A mother and her family will all be happier if she goes out to work.

(5) A father's job is to earn money; a mother's job is to look after the home and family.

Similar to their mothers, the cohort-members were asked to rate the level of their agreement from 1 (strongly disagree) to 5 (strongly agree). The proportions answering (1) to (5) for each statement are given in Appendix Table A2. A cohort member index of maternal gender role attitudes is formed by averaging answers (some reverse coded) and standardising such that the index is bound between 0 (traditional) and 1 (non-traditional). Clearly, the maternal and cohort-member indices of gender role attitudes are based on different questions. However, it seems reasonable to think that both sets of questions are capturing the same underlying latent attitude; namely, whether a mother should work outside the household domain or not.

The relationship between cohort members' gender role attitudes and their mothers' gender role attitudes is presented in Figure 2a, separately by cohort member gender (i.e. daughters and sons). ${ }^{3}$ The graph reveals a strong positive relationship in attitudes across generations, with the strength of association roughly equivalent for mother-daughters and mother-sons: the intergenerational correlation is approximately 0.13 for mother-daughters and 0.12 for mother-sons. ${ }^{4}$ Figure $2 \mathrm{a}$ also shows that the intergenerational relationships are roughly linear for maternal index values above 0.25 , which represents 98 percent of observations. This feature justifies the linearity assumption imposed in subsequent regression analyses. Values of the maternal index below 0.25 are rare, but when mothers have such strong traditional attitudes, Figure 2a suggests that the correlation is particularly high (approximately 0.18 for mother-daughters and 0.17 for mother-sons).

\footnotetext{
${ }^{3}$ One limitation of the data is that no information is collected on the gender role attitudes of fathers. Therefore, to the extent that there is assortative mating based on such attitudes, then the estimated correlation between maternal and child gender role attitudes might to some degree also capture paternal attitudes.

${ }^{4}$ Our indicators of gender role attitudes may only be noisy proxies of the true, latent attitudes an individual holds (Bertrand and Mullainathan, 2001). To gauge the magnitude of the measurement error we re-estimated a static simplification of a linear structural equation model as developed in Cunha and Heckman (2008). Such models are identified via variance-covariance restrictions, joint normality, and the presence of classical measurement error. When estimating a multiple indicator latent factor model, the standardized correlation between mothers' and daughters' and mothers' and sons' gender role attitudes is $0.17(0.012)$ and $0.14(0.013)$, respectively. Therefore, the intergenerational correlation of attitudes equalling 0.13 and 0.12 can be understood as lower-bound estimates.
} 


\subsection{Descriptive relationships between maternal gender role attitudes and child outcomes}

Figure $2 \mathrm{~b}$ presents relationships between maternal gender role attitudes in 1975 and the labour supply of their children and their daughters-in-law in 2000-2008. There is a strong positive and roughly linear relationship between a mother's non-traditional gender role attitudes and her daughter's probability of working full-time (solid line). In contrast, no obvious relationship can be found between a mother's attitudes and her son's probability of working (dotted line). Interestingly, a mother's attitudes towards maternal employment also determine the labour force status of her daughter-in-law (dashed line), suggesting that either sons match with equally traditional women or that there is contagion of attitudes between husband and wife. This relationship is particularly pronounced for mothers at the lower end of the attitude distribution (i.e. traditional mothers). In the following sections we investigate whether the positive maternal attitude effects shown in Figure $2 b$ are captured by background characteristics, cohort-members' own attitudes towards maternal employment and by intermediary educational attainment, marriage and fertility decisions.

One potentially important pathway between maternal attitudes and child labour market outcomes is human capital accumulation. Daughters of mothers with strongly traditional views may be discouraged from finishing school and attending university, given that the expected return to educational investments will be lower for daughters that are less likely to work throughout adulthood. Figure 3a illustrates the relationships between mothers' gender role attitudes and mothers' educational expectations (dropout of school at age 16, and attend university) in 1980 when their daughters are aged 10, and the observed educational attainment (dropout of school at age 16, and degree-holder) of their daughters. The figure shows that mothers with traditional views are more likely to expect their daughters to leave school at age 16, and are less likely to expect that their daughters will attend university. Similarly, daughters of mothers with traditional views are more likely to leave school at 16 and are less likely to attain a university degree. Therefore, human capital accumulation may be an important pathway through which maternal attitudes influence their daughters' adult labour market outcomes. Importantly, Figure $3 \mathrm{~b}$ shows that the relationships presented in Figure 3a for daughters do not hold for sons - traditional and non-traditional mothers have almost identical educational expectations for their sons.

\subsection{Control variables}

The variables used as controls in the regression analyses are listed in Appendix Table A3. These variables are used to capture any cohort-member or family characteristic that may have jointly affected both maternal attitudes and cohort-member labour supply. Most of the variables are measured in 1975, the same year that maternal attitudes and employment are measured. Particularly important cohort-member variables are cognitive test scores, which is an average score from 
English picture vocabulary, human figure drawing and copy designs tests conducted in 1975, and cohort member behavioural/emotional problems (sometimes labelled non-cognitive skills e.g. Heckman, 2007), which is the Rutter behavioural problems index (both scores are rescaled to range from zero to one). These variables control for cohort member 'ability', which is likely associated with maternal ability (and possibly maternal attitudes) and future labour market outcomes. Particularly important parental variables are maternal education, father social class and neighbourhood type - these variables control for family socioeconomic status, which is known to be strongly correlated across generations.

We further control for 'mother liberal parenting beliefs', which is an index created from mothers' responses to the attitude questionnaire. Responses to 16 attitude statements are used to create the index, with each of the 16 statements representing authoritarian or liberal parenting views. Some examples include "children should not be allowed to talk at the meal table", "unquestioning obedience is not a good thing in a young child", and "a well-brought up child is one who does not have to be told twice to do something". The index is constructed by averaging answers (some reverse coded) and standardising the score such that the index is bound between zero (authoritarian) and one (liberal). This control variable is positively correlated with maternal gender role attitudes (correlation equals 0.203), implying that more liberal parents are also more non-traditional on average. If parenting style is important for child development, then it is also likely that the liberal parenting index will be correlated with children's future labour market outcomes.

\section{Results}

\subsection{Intergenerational correlation in gender role attitudes}

The economic literature on the intergenerational transmission of values and preferences argues that parents' ultimate goal is to shape the choices of their children towards leading a healthy and successful life. In order to influence their children's choices, parents seek to actively influence the values and preferences of their children that are the underlying basis for making crucial life choices. Parents have the technology to influence their children's preferences by educating them at home (repeating verbally values), restricting their socialisation environment and peer groups (e.g. choice of neighbourhood, school), and influencing their marital decisions. Most theoretical and empirical papers tend to build on Bisin and Verdier (2001) who model parents as altruistic, yet paternalistic agents who maximise their children's future utility by choosing the degree to which their values are passed on to their children. Their model explicitly allows for neighbourhood effects, and thus parents choose the social environment for their children. This pathway of how values are transmitted between parents and their children has been laid out to explain the intergenerational transmission of risk preferences (Dohmen et al, 2011), patience (Doepke and Zilibotti, 2008), ethnic 
and religious traits (Bisin and Verdier, 2000), and corruption (Hauk and Saez-Marti, 2002).

Another related direct pathway is one of emulation, where children adopt the preferences and behaviour of their parents. Some studies show that as early as 18 months old, children will routinely copy even arbitrary and unnecessary actions that their parents take, which can include parents' talking styles, vocabulary use, and everyday behaviours. Evidence in the psychological literature suggests that over-imitation as a form to learn the use of objects and routines reflects an evolutionary adaptation that is fundamental to the development and transmission of human culture and may be common in all cultures (see Nielsen and Tomaselli, 2010, for an overview). One example of such research in the economics literature is Farrell and Shields (2007) who find evidence for this hypothesis, where children mimic their parent's expenditure patterns.

We begin by establishing the size of the correlation between mothers' (measured in 1975, when the cohort member was aged 5) and their daughters' and sons' own gender role attitudes (measured in 2000, at age 30). As well as a pooled model, Table 1 presents models fitted separately for daughters and sons. Each model conditions on actual maternal employment, distinguishing between mothers who worked full-time and part-time in 1975, so that we can test whether maternal attitudes (what I say) has a significant effect on children's attitudes, over and above the effect of maternal work (what I do). Each model also conditions on children's early life characteristics measured at age 5, namely, cognitive test scores, behavioural and emotional problems, number of medical conditions and birth-weight (recorded in the birth questionnaire in 1970). We also include a wide-range of family structure and socioeconomic characteristics in 1975 in order to control for the possibility that maternal attitudes and own attitudes are jointly determined by childhood economic circumstances. These are the number of older and younger siblings in the family, mother's and father's age, mother's and father's education, whether the mother smoked during pregnancy, whether the mother is single, father's occupational status, religion, and indicators of the socioeconomic status of the neighbourhood in which the family resided. Importantly, we also control for father's work status in 1975, to test whether father's work status is a significant predictor of his children's future gender role attitudes. Finally, to separately identify the effect of gender role attitudes from parenting styles, we include a measure of liberal parenting beliefs in the estimation equation.

We find a strong and significant intergenerational correlation in gender role attitudes, interestingly of roughly the same magnitude between mothers and sons, as mothers and daughters. Moving from the bottom to the top of the maternal attitudes score increases the daughter's score by 0.090 points and the son's score by 0.083 points. What the mother does is also a significant independent predictor of children's attitudes, though the effects are somewhat smaller in magnitude. Having a mother working full-time is associated with a 0.015 -point increase in children's attitudes, 
while a mother working part-time is associated with a 0.011-point increase. This suggests that what mothers say and what they do are both important mechanisms in explaining the intergenerational transmission of attitudes. These results, however, are less representative for men. Interestingly, if maternal attitudes are omitted from the regression models, the effects of maternal employment almost double: effects of full-time and part-time employment increase to 0.027 and 0.018 , respectively (results are provided upon request). This robustness check demonstrates that attitudes can be an important omitted variable in models of intergenerational outcomes.

Other interesting results from Table 1 are that cognitive test scores (an indicator of early intelligence) are a significantly positive predictor of daughters' future gender role attitudes, but no such relationship is found for sons. Boys growing up in a well-to-do (rich) neighbourhood are significantly more likely to hold traditional attitudes, but this association is not found for girls. As expected, religious beliefs of the family are also important in explaining gender role attitudes.

One potentially important difference between the cohort members in 2000 and their mothers in 1975 is that not all cohort members have children. To investigate the effect of this difference on the intergenerational correlation, we re-estimate the Table 1 regression specification for the sample of cohort members who have at least one child. The estimated effect for this subsample $(n=3,917)$ equals 0.077 . This estimate is only slightly smaller than the estimate from Column 1, suggesting there is not a significant difference in the intergenerational correlation coefficient for cohort members with and without children. We also test whether the intergenerational correlation differs depending upon whether or not the cohort members at age 30 were in regular contact with their mother (average age around 60). It is possible that the correlation is larger for those cohort members with regular contact because of cumulative exposure effects over time. The estimated effect for the regular contact subsample $(6,757$ observations) equals 0.084 .

The results shown in Table 1 and the sub-sample robustness results establish a strong and consistent intergenerational correlation in gender role attitudes. However, as discussed above, the cohort children's attitudes may have also been affected by the prevailing attitude within their neighbourhood. To investigate the impact of neighbourhood effects on the intergenerational correlation, we augment the Table 1 regression specifications with 248 indicators for the district (county) of residence in 1980. The estimated intergenerational correlation for the full sample equals 0.089, which is slightly (but not significantly) larger than the estimate from Table 1 . The corresponding estimates for daughter and son subsamples equal 0.098 and 0.081 , respectively. These three results indicate that neighbourhood effects do not mediate the mother-child relationship. We also investigated the role of neighbourhood effects by following the approach implemented in Dohmen et al. (2011), which involves adding to the Table 1 regression specification a variable 
representing the average gender role attitude in the district (excluding own maternal attitude). The coefficient for this variable was not statistically different from zero ( $p$-value equals 0.268 ).

As discussed in Fernandez and Fogli $(2006,2009)$ and Fernandez (2007) attitudes are often a function of family ancestry. The BCS data allows us to investigate this possibility because it contains information on mother's place of birth and grandmother's place of birth (regions within Britain, and countries outside of Britain). If we append indicators for mother's place of birth to the specification used in Table 1, we find that the intergenerational correlation is relatively unchanged (0.089). The intergenerational correlation is similarly unaffected if we instead append indicators for grandmother's place of birth (0.088). Interestingly, we also find that maternal attitudes are unrelated to their own place of birth (F-statistic equals 1.25) and to their mother's (grandmother of cohort member) place of birth (F-statistic equals 1.01).

So far we have focused on the intergenerational correlation using a continuous measure of attitudes. However, Figure 2a shows that the correlation may be particularly strong for mother-child pairs in which mothers are traditional. To allow for possible non-linearities in the intergenerational relationship we created binary variables representing attitudes scores of less than 0.5 . These variables roughly correspond to the $15 \%$ most traditional mothers and $25 \%$ most traditional cohort members. The estimated marginal effect of an especially traditional mother equals 0.056 for daughters and 0.095 for sons. In other words, sons with traditional mothers are 9.5 percentage points more likely to be traditional, or almost 40 percent more likely relative to the sample mean.

\subsection{Maternal gender role attitudes and children's labour supply}

Since we observe the labour supply choices of the cohort members up to three times (in 2000, 2004 and 2008) we estimate random effects Probit models of whether or not the cohort member is observed to be working full-time, and random effects Tobit models of their labour supply (hours worked). We also provide estimates of the relationship between maternal gender role attitudes, maternal employment status, and daughter-in-law employment status. This allows us to shed light on the question of whether sons marry their mothers, as found in previous research (e.g. Farré and Vella, 2007). The results from Probit random effects models of full-time employment are provided in Table 2, and those from random effects Tobit models are shown in Table 3. For all models the same set of child and family control variables as used in Table 1 are included.

Starting with the predicted effect of maternal attitudes and work status on children's full-time work status observed at ages 30, 34 and 38, we find that daughters raised by a mother with nontraditional gender role attitudes are significantly more likely to be observed working full-time. This effect is substantial, with a move from the bottom to the top on the maternal attitudes score 
increasing the probability of her daughter being in full-time employment by 29 percentage points. Importantly, no such effect is found for sons (-0.004).

Similar results are found for daughters in the hours worked Tobit model (Table 3), with the estimated Tobit coefficients showing that maternal gender role attitudes are a strong predictor of daughters' labour supply. Moving from the bottom to the top on the maternal attitudes score is associated with around 7 additional hours of work per week for daughters (Tobit model). Additionally, the mother's own employment is important, with a daughter whose mother worked full-time working about 2 hours more than a daughter whose mother did not work. The results also show that daughters' cognitive ability as measured at age 5 is a highly powerful predictor of her future labour supply, with the most cognitively developed children working 18 hours more per week than the least cognitively developed children. It is interesting that early life behavioural and emotional problems (non-cognitive skills) are not significantly related to daughter's future labour supply. We also find a positively strong and significant link between liberal parenting values and daughters labour supply (4.8 hours).

In contrast to the near-zero effect of maternal gender role attitudes on sons full-time employment status (Table 2), the Tobit model results in Table 3 suggest that sons with nontraditional mothers work fewer hours than sons with traditional mothers: moving from the bottom to the top of the index reduces weekly hours worked by 2.4 hours (effect significant at the $10 \%$ level). An explanation for the negative attitude effect is that sons with non-traditional mothers have lower labour supply in response to having a partner with higher labour supply (a household timeallocation decision). Evidence for daughters-in-laws, which we discuss in detail below, supports this hypothesis. Moreover, if we re-estimate the effect of gender role attitudes on hours worked separately for married and non-married sons, we find that the effect of maternal gender role attitudes is more negative for married sons. Similarly, the effect of maternal gender role attitudes is more negative for sons with children than for sons without children.

Table 3 also shows that cognitive ability and behavioural problems measured at age 5 are strong predictors of sons' labour supply, with high cognitive ability predicted to increase adult work-hours by 7.4 and frequent behavioural and emotional problems predicted to reduce workhours by 8.7 hours per week. The latter finding is in stark contrast to the findings for daughters. Another substantive difference between daughters and sons is the predicted role of liberal parenting styles. While we find that the daughters of mothers reporting a more liberal parenting style work more hours per week, the opposite is found for sons. In particular, the sons of parents who are very liberal in their parenting style work around 3 hours less per week than sons raised by more authoritarian parents, while daughters tend to work almost 5 hours more. This differential effect suggests that it is not simply the case that liberal parenting is capturing some omitted parent or 
family characteristic, because if this were the case it would likely generate consistent (in sign at least) results for daughters and sons.

\subsection{Maternal gender role attitudes and daughter-in-law labour supply}

In addition to the large positive effect of maternal attitudes on daughter employment outcomes, we find a large positive effect on daughter-in-law outcomes (Column 3, Table 2). Partners or spouses of men whose mothers held strongly non-traditional attitudes are estimated to be 12 percentage points more likely to work full-time. ${ }^{5}$ This most likely reflects assortative mating where sons choose partners with similar work attitudes to their mothers. An alternative pathway goes via household time allocation. Sons who hold non-traditional attitudes may be more likely to help out with household duties and also support their spouses with child-caring activities, freeing time for them to pursue their own career (Fernández et al., 2004). A third pathway is one of contagion, where gender role attitudes are passed on from husband to wife, which is then reflected in female labour supply, rather than a process of assortative mating on such attitudes in the marriage/partnering choice.

\subsection{Further exploring the pathways linking maternal gender role attitudes and child outcomes}

One potential pathway through which maternal gender role attitudes can affect future child labour supply is disparities in human capital investments. Traditional mothers are likely to have a higher expectation that their daughters will have interrupted spells of market employment, and hence have a smaller incentive to invest in their human capital. In other words, mothers who expect their daughters to pursue professional careers will invest more time and resources in their daughters' education than mothers who expect their daughters to be homemakers. Some empirical research supports this hypothesis. Vella (1994) using Australian data finds a strong negative impact of own traditional gender role attitudes on own educational attainment. González de San Román and de la Rica Goiricelaya (2012) find that differences in culture and social norms across regions are crucial determinants of gender differences in test scores, with girls performing relatively better in societies where gender equality is enhanced. In addition, the nonparametric associations shown above in Figure 3 provide empirical support for the relationship between maternal attitudes and human capital investments.

In Table 4 we investigate whether the relationships between maternal gender role attitudes (measured in 1975), expectations of daughters' educational attainment (measured in 1980), and daughters' actual highest level of education by 2004, remain statistically significant after controlling for confounding factors. Importantly though, we allow the relationship between

\footnotetext{
${ }^{5}$ Note that weekly work-hours information for daughters-in-law is not collected in the BCS.
} 
maternal gender role attitudes and daughter human capital to reflect the nonlinearities shown in Figure 3a. In particular, we estimate a piecewise linear function of maternal attitudes such that the linear effect of maternal attitudes below 0.5 (traditional) differs from the linear effect of maternal attitudes above 0.5 (non-traditional). The Probit regression results largely reflect the raw nonparametric relationships presented in Figure 3a. For maternal attitudes below 0.5, the effect of having less traditional attitudes significantly reduces school dropout expectations (-0.248), significantly reduces actual school dropouts (-0.418), and significantly increases degree attainment (0.338). To place these effect sizes in perspective, it is estimated that moving from a maternal attitude score of 0 (extremely traditional) to 0.5 (moderately traditional) reduces the probability of school dropout expectations by 12.4 percentage points and actual school dropouts by 20.9 percentage points, and increases the probability of attaining a university degree by 16.9 percentage points. Furthermore, we find that for maternal attitudes above 0.5 , the effect of having less traditional attitudes significantly increases university expectations (0.095). In summary, these results provide strong support for the hypothesis that maternal gender role attitudes impact upon human capital investments in daughters. No such relationship is found for sons.

Table 4 also shows that what mothers say (their attitudes) is more important than what they do (their own employment status) in determining their educational expectations for their daughters and their daughters' actual educational attainment. Another important determinant of mother's expectations of, and their daughters' actual, educational attainment is mother's own level of schooling, which is consistent with the finding that higher educated mothers invest more in their children (e.g. Carneiro et al., 2012). Also, the child's own cognitive ability is an important determinants of schooling outcomes, which is a standard result in the literature (see Cawley et al., 2001, for an overview).

For sons, the estimated attitude effects are all small and statistically insignificant, indicating that maternal gender role attitudes do not impact upon human capital investments in sons. However, we do find evidence for their effect on daughter-in-law educational attainment. It is estimated that moving from a maternal attitude score of 0 (extremely traditional) to 0.5 (moderately traditional) reduces the probability that the daughter-in-law left full-time education at age 16 by 17.2 percentage points ( $\mathrm{p}$-value equals 0.060) (results provided upon request). This result provides further evidence of assortative mating, whereby sons choose partners with similar attitudes to themselves and their mothers.

Table 5 presents results from Probit random effects models of daughters' full-time employment and linear random effects models of daughters' weekly work hours. The models attempt to determine whether the strong relationship between daughters' labour supply and maternal gender role attitudes (what I say) and maternal employment (what I do) is driven primarily by the 
pathway of differences in maternal educational expectations and daughters educational attainment. The first column of results replicates those provided for daughters in Table 2. The second column adds covariates representing maternal education expectations (leave school at 16, attend university). Even though both education expectations are highly significant predictors of employment, the marginal effect estimates for maternal gender role attitudes falls only slightly ( 0.287 to 0.277 ). Adding in measures of actual educational attainment further reduces the estimate to 0.263 . The same pattern across columns is found for the Tobit work-hours models.

Maternal attitudes may also affect daughters' labour supply by altering daughters' marriage and fertility decisions. It is possible that daughters with strongly traditional mothers are more likely to marry and to have children, which in turn may reduce their labour supply. We test this hypothesis by adding covariates to the daughters' employment and working hours models that represent children and marital status at age 30 (in year 2000). The results suggest that marriage and fertility decisions are not prime pathways between maternal attitudes and daughters' labour supply, as the estimates presented in columns 4 and 8 are near identical to previous estimates. Lastly, the effect of maternal attitudes prevails even when controlling for the daughter's own gender role attitudes measured in 2000, although the effect is about $40 \%$ smaller $(0.155, \mathrm{SE}=0.070)$. This suggests that maternal gender role attitudes have a long lasting independent effect on her daughter's labour supply decisions.

\subsection{Fixed-effects estimates of maternal gender role attitudes on daughter's labour supply}

The longitudinal nature of the cohort-member labour supply data provides us with an additional opportunity to investigate the pathways linking maternal gender role attitudes and daughters' outcomes. In particular, we are able to test whether the effects of maternal attitudes on daughters' labour supply, shown in Tables 2 and 3, grow or diminish with age or with other changes in daughters' lives. Our approach is to estimate linear fixed-effect models of full-time employment status and work hours with time-varying characteristics representing children, marriage, health and age - naturally, all the time-invariant characteristics reported in previous tables are subsumed by the individual-level fixed effect. In the models we also add interaction terms between some of the timevarying characteristics and (demeaned) maternal gender-role attitudes. The results are presented in Table 6.

Unsurprisingly, the fixed-effects results show that female cohort members substantially reduce their labour supply after having children, both in terms of hours worked and their probability of working at all. However, the effects differ substantially between daughters whose mothers' had non-traditional and traditional beliefs. For daughters with traditional mothers (index equals 0), the probability of full-time employment reduces by 55.6 percentage points and the number of hours 
worked reduces by 19.9 hours after having children. This large negative effect of child birth is significantly less negative for women whose mothers held strongly non-traditional gender role attitudes: the estimated effect of children on full-time employment (hours worked) for women with non-traditional mothers (index equals 1) equals $-0.342(-12.371)$, where the difference is equal to the estimated interaction effect of 0.213 (7.524). This result indicates that the effects of maternal attitudes are not constant throughout a women's working life, but rather have a particularly large effect on women's labour supply when they themselves have children. In contrast, the remaining results in Table 6 indicate that the labour supply effects of maternal attitudes do not change with age or marital status.

\section{Conclusions}

In this paper we have contributed to a better understanding of the mechanisms underlying the strong and persistent intergenerational correlation in economic outcomes. We investigated the extent to which mothers' attitudes towards women's roles in the labour market (traditional versus nontraditional attitudes) are correlated with their children's own beliefs when they are adults, and the extent to which both the attitudes (what I say) and labour supply decisions of mothers (what I do) predict their children's own future labour supply decisions. This important later distinction is relatively under-researched. We have also focused on daughters-in-law to establish if sons of mothers with pro-gender-equality attitudes are more likely to be married or cohabiting with women who are working full-time. This informs on the issues of assortative mating based on work preferences. Our empirical analysis is based on data drawn from the British Cohort Study, which has followed individuals born in one particular week in April 1970 until 2008 (age 38). Mothers' attitudes towards women's role in the labour market are measured in 1975 when the cohort member was aged 5, and the cohort member's own attitudes are measured at age 30 (in 2000) and employment status is repeatedly measured in 2000, 2004 and 2008.

We find that mothers' and children's gender role attitudes are strongly correlated with a magnitude that is comparable to those found in the only two studies that also quantified the intergenerational transmission using US data (see Farré and Vella, 2009; and Moen et al., 1997). Interestingly, the strength of this intergenerational correlation is the same between mothers and daughters, and mothers and sons. However, mothers' attitudes are only strongly predictive of daughters' future labour supply, with a move from the bottom (traditional) to top (non-traditional) of the maternal gender role attitudes index increasing daughters' probability of being employed fulltime by around 29 percentage points. This effect is almost four times as large as the effect of mother's own full-time employment status when her daughter was 5 years old, and half the effect of 
moving from the bottom to the top of the cognitive ability scale. The estimated effect for sons equalled 0.4 percentage points and was statistically insignificant.

The differential effect between daughters and sons suggests that maternal gender role attitudes are not simply capturing an important omitted parental or family characteristic that would jointly promote labour supply for both sons and daughters. This is also supported by our finding that sons 'marry their mothers' in the sense that maternal attitudes are a significant positive predictor of daughter-in-law labour supply, a hypothesis suggested in Fernández et al. (2004). A plausible candidate to explain the daughter-in-law relationship is assortative mating, where sons marry women with similar beliefs and preferences, but we cannot fully rule out a contagion effect where over time daughters-in-law adopt their husband/partners' attitudes toward gender roles (traditional versus non-traditional) in the home and labour market.

A key potential pathway through which traditional maternal gender role attitudes can affect children's future labour supply is human capital accumulation. Our hypothesis is that nontraditional mothers will devote more time and/or resources to their daughters' education, relative to mothers who hold traditional beliefs about women's role in society. To test this hypothesis we have used information collected from mothers in 1980 (when the cohort member is aged 10) about their education expectations, in particular whether they believed their child would leave school at age 16 (at the end of the minimum compulsory schooling) and whether they would attain a university degree level education. We find strong support for this hypothesis with maternal attitudes negatively related to school dropout expectations and actual school dropouts, and positively related to university expectations and university degree attainment. These significant effects were found even after controlling for a wide-range of child (including measures of cognitive and non-cognitive ability), parental (including education and occupational status) and family (sibling composition, religion, neighbourhood) characteristics. Further investigation finds that while some of the intergenerational correlation in gender role work attitudes is explained by this human capital mechanism, a large component still remains unexplained.

Finally, results from individual fixed-effects models show that the labour supply effects of maternal gender role attitudes do not change with daughters' age or marital status, but do significantly increase when the daughter has children of her own. This supports the importance of the long-term effect of maternal gender role attitudes as a key mechanism in explaining persisting gender-inequalities in educational attainment and lifetime labour supply. 


\section{References}

Baron, JD., Cobb-Clark, DA. and Erkal, N. (2008). Cultural transmission of work-welfare attitudes and the intergenerational correlation in welfare receipt. IZA Discussion Paper 3904, Bonn.

Bisin, A. and Verdier, T. (2000). Beyond the melting pot: Cultural transmission, marriage, and the evolution of ethnic and religious traits. Quarterly Journal of Economics, 115, pp. 955-88.

Bisin, A. and Verdier, T. (2001). The economics of cultural transmission and the dynamics of preferences. Journal of Economic Theory, 97, pp. 298-319.

Black. SE. and Devereux, PJ. (2011). Recent developments in intergenerational mobility. In Ashenfelter, OC. and Card, D. (eds), Handbook of Labor Economics, Vol. 4., pp. 1487-1541, Elsevier.

Bertrand, M. and Mullainathan, S. (2001). Do people mean what they say? Implications for subjective survey data. American Economic Review, 91, pp. 67-72.

Carneiro, PC., Meghir, C. and Parey, M. (2012). Maternal education, home environment and child development. Journal of the European Economic Association, forthcoming.

Cawley, J. and Heckman, JJ. (2001). Three observations on wages and measured cognitive ability. Labour Economics, 8, pp. 419-442.

Chamberlain, G. (1975). British Births 1970. London, Heinemann.

Cunha, F. and Heckman, JJ. (2008). Formulating, identifying and estimating the technology of cognitive and noncognitive skill formation. Journal of Human Resources, 43, pp. 738-782.

Currie, J. (2009). Healthy, wealthy, and wise: Socioeconomic status, poor health in childhood, and human capital development. Journal of Economic Literature, 47, pp. 87-122.

Dearden, L., Machin, S. and Reed, H. (1997). Intergenerational mobility in Britain. Economic Journal, 107, pp. 47-66.

Doepke, M. and Zilibotti, F. (2008). Occupational choice and the spirit of capitalism. Quarterly Journal of Economics, 123, pp. 747-93.

Dohmen, T., Falk, A., Huffman, D. and Sunde, U. (2010). Are risk aversion and impatience related to cognitive ability?. American Economic Review, 100, pp. 1238-1260.

Dohmen, T., Falk, A., Huffman, D. and Sunde, U. (2011). The intergenerational transmission of risk and trust attitudes. Review of Economic Studies, forthcoming.

Farré, L. and Vella, F. (2007). The intergenerational transmission of gender role attitudes and its implications for female labor force participation. IZA Discussion Paper. Institute for the Study of Labor (IZA), Bonn.

Farrell, L. and Shields, MA. (2007). Children as consumers: Investigating child diary expenditure data. Canadian Journal of Economics, 40, pp. 445-467.

Fernandez, R. (2007). Women, work and culture. Journal of the European Economic Association, 5, pp. 305-332.

Fernandez, R. and Fogli, A. (2009). Culture: An empirical investigation of beliefs, work, and fertility. American Economic Journal: Macroeconomics, 1, pp. 146-77.

Fernández, R., Fogli, A. and Olivetti, C. (2004). Mothers and sons: Preference formation and female labor force dynamics. Quarterly Journal of Economics, 119, pp. 1249-99.

Fortin, NM. (2005). Gender role attitudes and the labour-market outcomes of women across OECD countries. Oxford Review of Economic Policy, 21, pp. 416-38.

Fortin, NM. (2009). Gender role attitudes and women's labor market participation: opting out, AIDS, and the persistent appeal of housewifery.Working paper, University of British Columbia.

Guiso, L., Monte, F., Sapienza, P. and Zingales, L. (2008). Culture, gender and math. Science, 320, pp. 1164-65.

Guiso, L., Sapienza, P. and Zingales, L. (2006). Does culture affect economic outcomes? Journal of Economic Perspectives, 20, pp. 23-48.

González de San Román, A. and De la Rica Goiricelaya, S. (2012). Gender gaps in Pisa Test Scores: The impact of social norms and the mother's transmission of role attitudes. IZA Discussion Paper, Institute for the Study of Labor (IZA), Bonn. 
Hauk, E. and Saez-Marti, M. (2002). On the cultural transmission of corruption. Journal of Economc Theory, 107, pp. 311-35.

Haveman, R. and Wolfe, B. (1995). The determinants of children's attainments: A review of methods and findings. Journal of Economic Literature, 33, pp. 1829-1878.

Heckman, JJ. (2007). The technology and neuroscience of capacity formation. PNAS, 104, pp. 13250-13255.

Kawaguchi, D. and Miyazaki, J. (2009). Working mothers and sons' preferences regarding female labor supply: Direct evidence from stated preferences. Journal of Population Economics, 22, pp. 115-30.

Levine, DI. (1993). The effect of non-traditional attitudes on married women's labor supply. Journal of Economic Psychology, 14, pp. 665-79.

Mazumder, B. (2005). Fortunate sons: New estimates of intergenerational mobiliy in the United States using social security earnings data. Review of Economics and Statistics, 87, pp. 235-255.

Moen, P., Erickson, MA. and Dempster-McClain, D. (1997). Their mother's daughters? The intergenerational transmission of gender attitudes in a world of changing roles. Journal of Marriage and Family, 59, pp. 281-93.

Nielsen, M. and Tomaselli, K. (2010). Overimitation in Kalahari Bushman children and the origins of human cultural cognition. Psychological Science, April 16.

Powell, B. and Carr Steelman, L. (1982). Testing an undertested comparison: Maternal effects on sons' and daughters' attitudes toward women in the labor force. Journal of Marriage and Family, 44, pp. 349-55.

Solon, G. (1999). Intergenerational mobility in the labor market. In Ashenfelter, O. and Card, D. (ed.), Handbook of Labor Economics, Ed. 1, Vol. 3, pp. 1761-1800, Elsevier.

Thornton, A. and Freedman, D. (1979). Changes in the sex-role attitudes of women, 1962-1977. American Sociological Review, 44, pp. 831-42.

Vella, F. (1994). Gender roles and human capital investment: The relationship between traditional attitudes and female labour market performance. Economica, 61, pp. 191-211. 
Figure 1: Kernel Density Estimates of Maternal Gender Role Attitudes Index

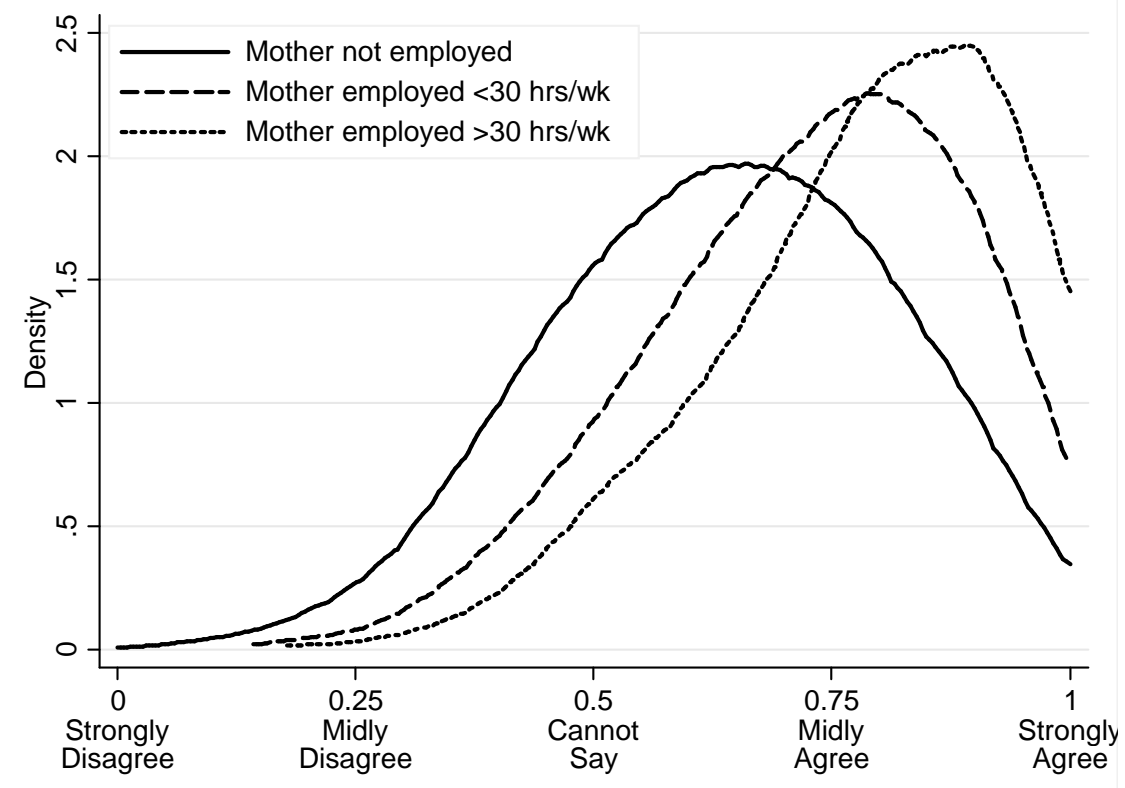

Figure 2: Estimated Non-Parametric Effects of Maternal Gender Role Attitude

2a: Child's gender role attitudes

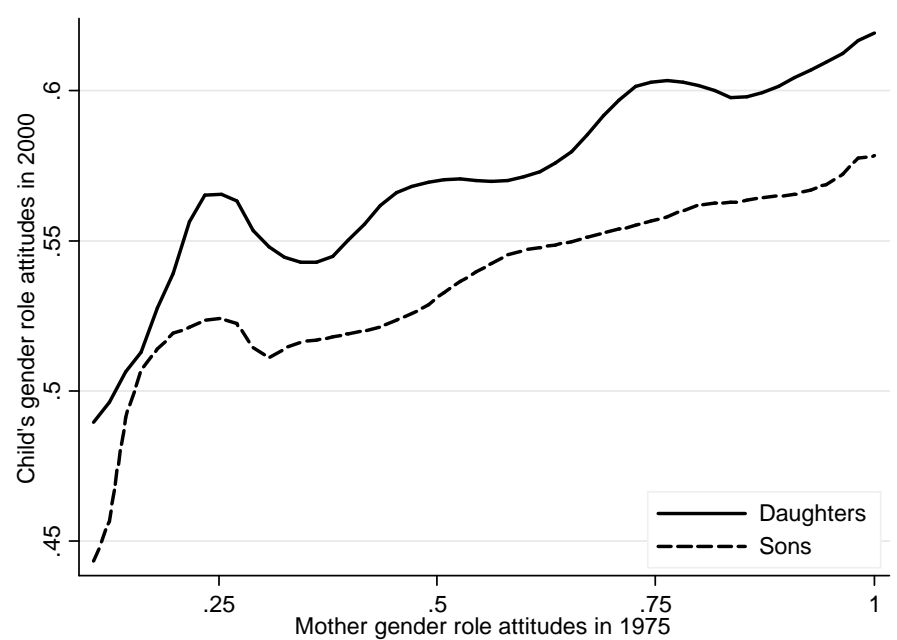

2b: Full-time employment

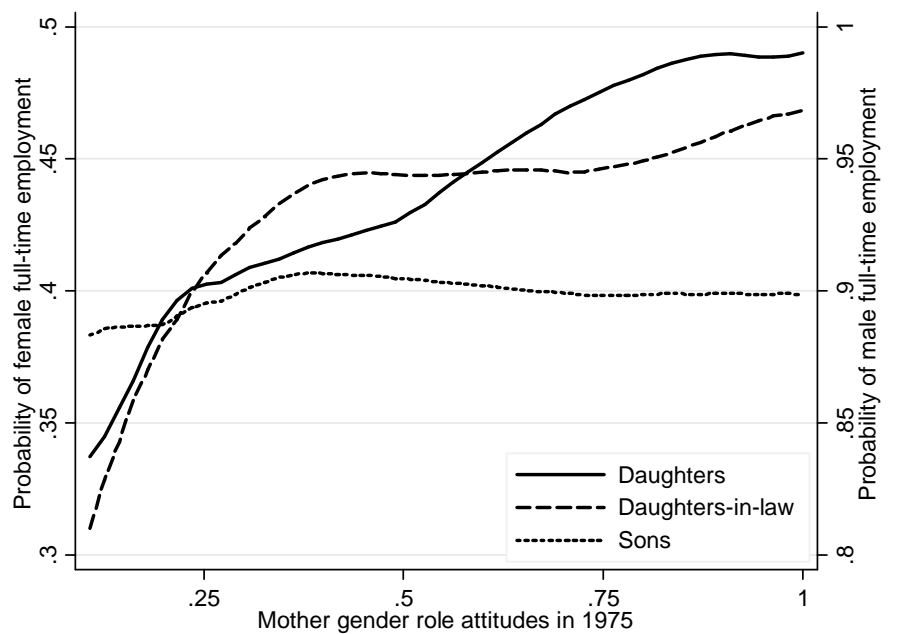


Figure 3: Estimated Non-Parametric Relationships between Maternal Gender Role Attitudes and Expected and Actual Educational Attainment

3a: Daughters

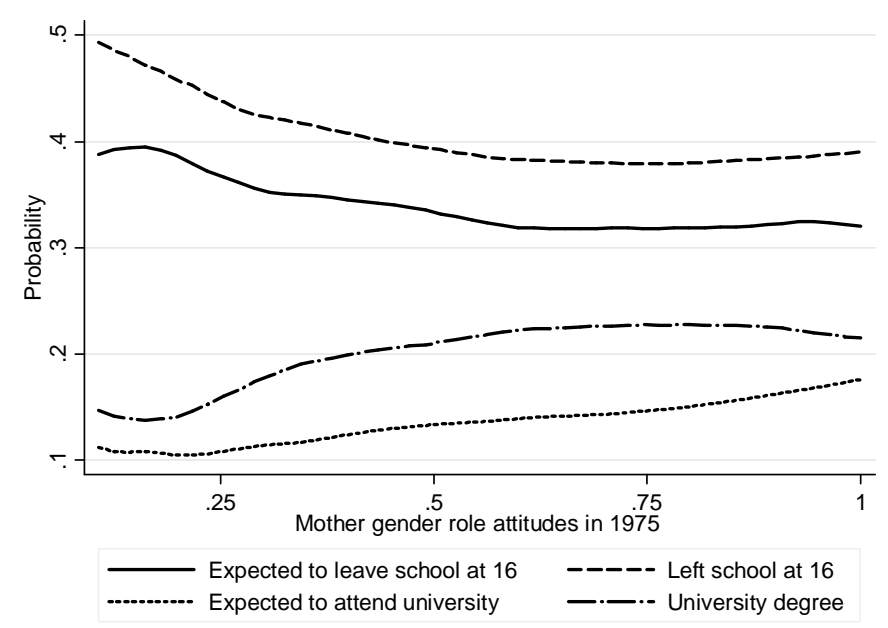

3b: Sons

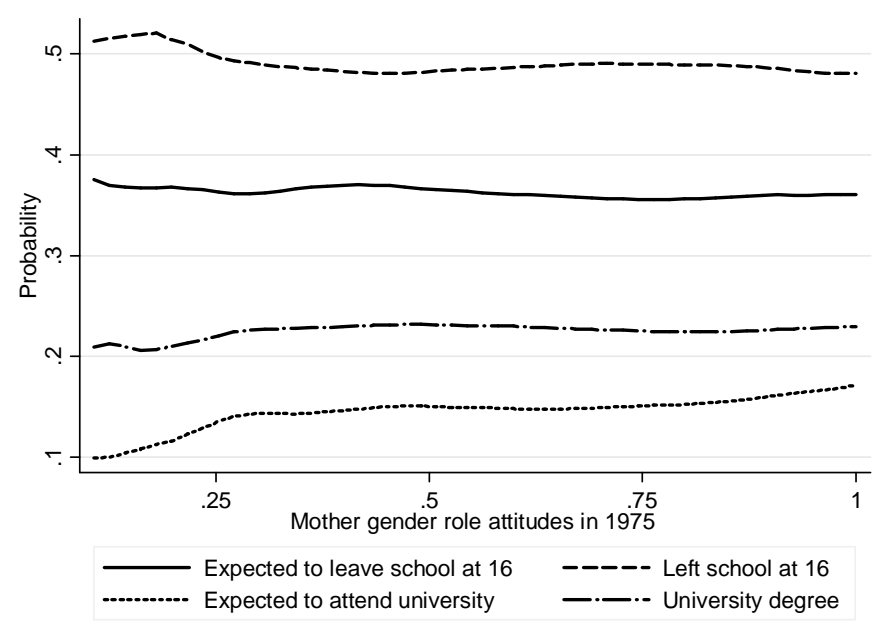


Table 1:

Linear Regression Models of Cohort Child's Gender Role Attitudes in 2000

\begin{tabular}{|c|c|c|c|c|c|c|}
\hline & \multicolumn{2}{|c|}{ All Children } & \multicolumn{2}{|c|}{ Daughters } & \multicolumn{2}{|c|}{ Sons } \\
\hline & $\beta$ & $(\mathrm{se})$ & $\beta$ & $(\mathrm{se})$ & $\boldsymbol{\beta}$ & (se) \\
\hline Mother gender role attitudes & $0.086^{* * *}$ & $(0.009)$ & $0.090^{* * * *}$ & $(0.013)$ & $0.083^{* * *}$ & $(0.013)$ \\
\hline Mother employed < 30 hours pw & $0.011^{\text {*** }}$ & $(0.004)$ & $0.014^{* * * *}$ & $(0.005)$ & 0.006 & $(0.005)$ \\
\hline Mother employed $\geq 30$ hours pw & $0.015^{* *}$ & $(0.006)$ & $0.015^{*}$ & $(0.009)$ & 0.014 & $(0.009)$ \\
\hline Male & $-0.037^{* * * *}$ & $(0.003)$ & - & - & - & - \\
\hline Number of younger sisters & $0.006^{*}$ & $(0.003)$ & $0.009^{* *}$ & $(0.005)$ & 0.000 & $(0.005)$ \\
\hline Number of older sisters & -0.001 & $(0.002)$ & 0.001 & $(0.003)$ & -0.002 & $(0.003)$ \\
\hline Number of younger brothers & -0.001 & $(0.003)$ & 0.003 & $(0.005)$ & -0.006 & $(0.005)$ \\
\hline Number of older brothers & -0.000 & $(0.002)$ & -0.003 & $(0.003)$ & 0.002 & $(0.003)$ \\
\hline Cognitive test score & $0.033^{* * *}$ & $(0.012)$ & $0.069^{* * * *}$ & $(0.017)$ & 0.001 & $(0.016)$ \\
\hline Behavioural/emotional problems & -0.018 & $(0.013)$ & -0.017 & $(0.019)$ & -0.019 & $(0.018)$ \\
\hline Number of medical conditions & -0.001 & $(0.001)$ & -0.002 & $(0.002)$ & -0.001 & $(0.001)$ \\
\hline Low birth weight & 0.006 & $(0.007)$ & $0.019^{* *}$ & $(0.009)$ & -0.007 & $(0.010)$ \\
\hline Mother age & 0.000 & $(0.000)$ & -0.000 & $(0.001)$ & 0.001 & $(0.001)$ \\
\hline Mother smoked during pregnancy & $-0.009^{* * *}$ & $(0.003)$ & $-0.009^{*}$ & $(0.005)$ & $-0.009^{*}$ & $(0.005)$ \\
\hline Mother years of education & 0.001 & $(0.001)$ & 0.001 & $(0.002)$ & 0.001 & $(0.002)$ \\
\hline Mother liberal parenting beliefs & 0.013 & $(0.012)$ & 0.025 & $(0.016)$ & 0.001 & $(0.016)$ \\
\hline Mother single & -0.004 & $(0.011)$ & -0.002 & $(0.015)$ & -0.007 & $(0.015)$ \\
\hline Father age & -0.000 & $(0.000)$ & -0.000 & $(0.001)$ & -0.001 & $(0.001)$ \\
\hline Father years of education & 0.001 & $(0.001)$ & 0.001 & $(0.001)$ & 0.002 & $(0.001)$ \\
\hline Father employed & 0.007 & $(0.007)$ & 0.014 & $(0.010)$ & 0.000 & $(0.010)$ \\
\hline Father SC: non-manual skilled & 0.001 & $(0.006)$ & -0.009 & $(0.009)$ & $0.014^{*}$ & $(0.008)$ \\
\hline Father SC: manual skilled & -0.001 & $(0.004)$ & -0.005 & $(0.006)$ & 0.003 & $(0.006)$ \\
\hline Father SC: semi-skilled & -0.005 & $(0.006)$ & -0.010 & $(0.008)$ & 0.000 & $(0.008)$ \\
\hline Father SC: unskilled & 0.014 & $(0.009)$ & 0.016 & $(0.013)$ & 0.013 & $(0.013)$ \\
\hline Neighbourhood: poor & -0.001 & $(0.007)$ & -0.000 & $(0.010)$ & -0.002 & $(0.010)$ \\
\hline Neighbourhood: well-to do & $-0.008^{*}$ & $(0.004)$ & -0.004 & $(0.006)$ & $-0.012^{* *}$ & $(0.006)$ \\
\hline Neighbourhood: rural & $-0.008^{*}$ & $(0.004)$ & -0.007 & $(0.006)$ & -0.009 & $(0.006)$ \\
\hline Religion: Church of England & $-0.011^{* * * *}$ & $(0.004)$ & $-0.011^{*}$ & $(0.006)$ & -0.009 & $(0.005)$ \\
\hline Religion: Catholic & -0.004 & $(0.006)$ & 0.003 & $(0.008)$ & -0.012 & $(0.008)$ \\
\hline Religion: other-Christian & $-0.028^{* * * *}$ & $(0.005)$ & $-0.031^{* * *}$ & $(0.007)$ & $-0.023^{* * *}$ & $(0.006)$ \\
\hline Religion: other non-Christian & $-0.024^{* *}$ & $(0.012)$ & 0.016 & $(0.017)$ & $-0.065^{* * *}$ & $(0.017)$ \\
\hline Sample size & 8,683 & & 4,464 & & 4,219 & \\
\hline
\end{tabular}

Notes: Absolute standard errors are presented in parentheses. *** and *** signify statistical significance at $0.10,0.05$ and 0.01 levels. All models also control for year (2000, 2004, 2008) and region (North, York, North-West, East-Midlands West-Midlands East-Anglia, South-West, South-East, Wales, Scotland). Omitted categorical variables are: Father SC: professionals and managers; Neighbourhood: average; Religion: none. All covariates in daughter-in-law model take son (husband) values. 
Table 2:

Random-Effect Probit Regression Models of Full-Time Employment Status in 2000-2008

\begin{tabular}{|c|c|c|c|c|c|c|}
\hline & \multicolumn{2}{|c|}{ Daughter } & \multicolumn{2}{|c|}{ Son } & \multicolumn{2}{|c|}{ Daughter-in-law } \\
\hline & ME & (se) & ME & (se) & ME & $(\mathrm{se})$ \\
\hline Mother gender role attitudes & $0.287^{* * * *}$ & $(0.068)$ & -0.004 & $(0.004)$ & $0.119^{*}$ & $(0.062)$ \\
\hline Mother employed $<30$ hours pw & 0.042 & $(0.026)$ & $0.003^{* *}$ & $(0.001)$ & 0.012 & $(0.025)$ \\
\hline Mother employed $\geq 30$ hours pw & $0.082^{*}$ & $(0.045)$ & $0.006^{* * *}$ & $(0.001)$ & -0.029 & $(0.040)$ \\
\hline Number of younger sisters & -0.003 & $(0.025)$ & -0.002 & $(0.001)$ & -0.016 & $(0.024)$ \\
\hline Number of older sisters & $-0.084^{* * *}$ & $(0.016)$ & -0.001 & $(0.001)$ & -0.015 & $(0.016)$ \\
\hline Number of younger brothers & $-0.043^{*}$ & $(0.024)$ & -0.000 & $(0.001)$ & -0.019 & $(0.024)$ \\
\hline Number of older brothers & $-0.087^{* * *}$ & $(0.017)$ & -0.001 & $(0.001)$ & -0.018 & $(0.014)$ \\
\hline Cognitive test score & $0.537^{* * *}$ & $(0.090)$ & $0.022^{* * *}$ & $(0.006)$ & $0.210^{* * *}$ & $(0.081)$ \\
\hline Behavioural/emotional problems & -0.001 & $(0.099)$ & $-0.023^{* * *}$ & $(0.007)$ & -0.076 & $(0.091)$ \\
\hline Number of medical conditions & -0.007 & $(0.008)$ & -0.000 & $(0.000)$ & 0.007 & $(0.006)$ \\
\hline Low birth weight & -0.023 & $(0.048)$ & -0.002 & $(0.003)$ & 0.059 & $(0.050)$ \\
\hline Mother age & $0.007^{* *}$ & $(0.004)$ & -0.000 & $(0.000)$ & $0.005^{*}$ & $(0.003)$ \\
\hline Mother smoked during pregnancy & $-0.071^{* * *}$ & $(0.024)$ & -0.000 & $(0.001)$ & -0.019 & $(0.023)$ \\
\hline Mother years of education & 0.008 & $(0.009)$ & 0.001 & $(0.001)$ & 0.002 & $(0.008)$ \\
\hline Mother liberal parenting beliefs & $0.142^{*}$ & $(0.084)$ & -0.007 & $(0.005)$ & 0.018 & $(0.077)$ \\
\hline Mother single & 0.037 & $(0.078)$ & -0.021 & $(0.016)$ & $-0.162^{* *}$ & $(0.063)$ \\
\hline Father age & 0.005 & $(0.003)$ & -0.000 & $(0.000)$ & 0.002 & $(0.003)$ \\
\hline Father years of education & -0.000 & $(0.007)$ & -0.000 & $(0.000)$ & 0.001 & $(0.007)$ \\
\hline Father employed & $0.158^{* * *}$ & $(0.050)$ & $0.008^{* *}$ & $(0.004)$ & 0.038 & $(0.047)$ \\
\hline Father SC: non-manual skilled & -0.022 & $(0.044)$ & $0.004^{* * *}$ & $(0.002)$ & -0.032 & $(0.039)$ \\
\hline Father SC: manual skilled & $-0.070^{* *}$ & $(0.031)$ & -0.001 & $(0.002)$ & $-0.061^{* *}$ & $(0.029)$ \\
\hline Father SC: semi-skilled & $-0.069^{*}$ & $(0.041)$ & -0.000 & $(0.003)$ & -0.041 & $(0.040)$ \\
\hline Father SC: unskilled & $-0.141^{* *}$ & $(0.058)$ & -0.002 & $(0.004)$ & -0.006 & $(0.063)$ \\
\hline Neighbourhood: poor & -0.046 & $(0.048)$ & $-0.021^{* *}$ & $(0.010)$ & -0.028 & $(0.049)$ \\
\hline Neighbourhood: well-to do & 0.017 & $(0.031)$ & 0.001 & $(0.002)$ & 0.016 & $(0.029)$ \\
\hline Neighbourhood: rural & 0.036 & $(0.032)$ & $0.003^{* *}$ & $(0.001)$ & -0.026 & $(0.029)$ \\
\hline Religion: Church of England & $-0.125^{* * * *}$ & $(0.030)$ & $0.007^{* * * *}$ & $(0.002)$ & $-0.104^{* * *}$ & $(0.026)$ \\
\hline Religion: Catholic & $0.071^{*}$ & $(0.043)$ & $0.003^{* *}$ & $(0.001)$ & $-0.065^{*}$ & $(0.038)$ \\
\hline Religion: other-Christian & -0.042 & $(0.034)$ & $0.005^{* * *}$ & $(0.002)$ & $-0.089^{* * *}$ & $(0.029)$ \\
\hline Religion: other non-Christian & -0.019 & $(0.085)$ & -0.022 & $(0.017)$ & -0.043 & $(0.080)$ \\
\hline Sample size & 11,628 & & 10,425 & & 7,282 & \\
\hline
\end{tabular}

Notes: Figures are marginal effect estimates calculated at mean covariate values. Absolute standard errors are presented in parentheses. $* * *$ and $* * *$ signify statistical significance at $0.10,0.05$ and 0.01 levels. All models also control for year (2000, 2004, 2008) and region (North, York, North-West, East-Midlands West-Midlands East-Anglia, South-West, SouthEast, Wales, Scotland). Omitted categorical variables are: Father SC: professionals and managers; Neighbourhood: average; Religion: none. All covariates in daughter-in-law model take son (husband) values. 
Table 3:

Random-Effect Tobit Regression Models of Work Hours in Years 2000-2008

\begin{tabular}{l|cc|cc}
\hline & \multicolumn{2}{|c|}{ Daughters } & \multicolumn{2}{c}{ Sons } \\
\hline & $\boldsymbol{\beta}$ & $(\mathrm{se})$ & $\boldsymbol{\beta}$ & $(\mathrm{se})$ \\
\hline Mother gender role attitudes & $7.132^{* * * *}$ & $(1.765)$ & $-2.428^{* *}$ & $(1.350)$ \\
Mother employed < 30 hours pw & $1.998^{* * *}$ & $(0.682)$ & $0.994^{* *}$ & $(0.538)$ \\
Mother employed $\geq 30$ hours pw & $2.594^{* *}$ & $(1.150)$ & $4.008^{* * * *}$ & $(0.904)$ \\
Cognitive test score & $17.524^{* * *}$ & $(2.317)$ & $7.352^{* * *}$ & $(1.710)$ \\
Behaviour/emotion problems & -1.460 & $(2.562)$ & $-8.678^{* * *}$ & $(1.958)$ \\
Mother years of education & 0.170 & $(0.226)$ & $0.298^{* *}$ & $(0.175)$ \\
Mother liberal parenting beliefs & $4.819^{* * *}$ & $(2.190)$ & $-3.182^{*}$ & $(1.706)$ \\
Father social class: unskilled & $-7.678^{* * *}$ & $(1.728)$ & -1.888 & $(1.337)$ \\
\hline Sample size & 11377 & & 10176 & \\
\hline
\end{tabular}

Notes: Selected coefficient estimates shown. All models include covariates displayed in Tables 1 and 2 plus year and region effects. Standard errors are presented in parentheses. *, $* *$ and $* * *$ signify statistical significance at $0.10,0.05$ and 0.01 levels. In daughters' and sons' Tobit models, 2793 and 825 observations are censored at zero, respectively. 
Table 4:

Probit Regression Models of Education Expectations and Attainment

\begin{tabular}{|c|c|c|c|c|c|c|c|c|}
\hline & \multicolumn{2}{|c|}{$\begin{array}{c}\text { Expected to leave } \\
\text { school at } 16\end{array}$} & \multicolumn{2}{|c|}{$\begin{array}{c}\text { Expected to attend } \\
\text { university }\end{array}$} & \multicolumn{2}{|c|}{ Left school at 16} & \multicolumn{2}{|c|}{$\begin{array}{c}\text { Attained } \\
\text { University degree }\end{array}$} \\
\hline & $\mathrm{ME}$ & $(\mathrm{se})$ & $\mathrm{ME}$ & $(\mathrm{se})$ & $\mathrm{ME}$ & (se) & $\mathrm{ME}$ & $(\mathrm{se})$ \\
\hline \multicolumn{9}{|l|}{ Daughters } \\
\hline Mother gender role attitudes $<0.5$ & $-0.248^{*}$ & $(0.151)$ & 0.042 & $(0.112)$ & $-0.418^{* *}$ & $(0.166)$ & $0.338^{* *}$ & $(0.140)$ \\
\hline Mother gender role attitudes $>0.5$ & 0.047 & $(0.055)$ & $0.095^{* *}$ & $(0.037)$ & -0.006 & $(0.060)$ & -0.029 & $(0.047)$ \\
\hline Mother employed < 30 hours pw & -0.005 & $(0.017)$ & -0.017 & $(0.011)$ & $0.031^{*}$ & $(0.018)$ & -0.003 & $(0.014)$ \\
\hline Mother employed $\geq 30$ hours pw & $-0.063^{* *}$ & $(0.025)$ & -0.007 & $(0.018)$ & 0.038 & $(0.031)$ & 0.001 & $(0.023)$ \\
\hline Cognitive test score & $-0.566^{* * *}$ & $(0.056)$ & $0.333^{* * *}$ & $(0.039)$ & $-0.473^{* * *}$ & $(0.061)$ & $0.559^{* * *}$ & $(0.048)$ \\
\hline Behaviour/emotion problems & $0.152^{* *}$ & $(0.061)$ & $-0.095^{* *}$ & $(0.044)$ & 0.024 & $(0.066)$ & $-0.121^{* *}$ & $(0.054)$ \\
\hline Mother years of education & $-0.064^{* * *}$ & $(0.008)$ & $0.019^{* * *}$ & $(0.003)$ & $-0.064^{* * *}$ & $(0.008)$ & $0.026^{* * *}$ & $(0.004)$ \\
\hline Mother liberal parent & $-0.241^{* * *}$ & $(0.055)$ & $0.060^{*}$ & $(0.035)$ & -0.021 & $(0.058)$ & $0.137^{* * *}$ & $(0.044)$ \\
\hline Father social class: unskilled & $0.184^{* * *}$ & $(0.045)$ & $-0.065^{* * *}$ & $(0.020)$ & $0.198^{* * *}$ & $(0.045)$ & $-0.100^{* * *}$ & $(0.025)$ \\
\hline Sample size & 4449 & & 4449 & & 4449 & & 4449 & \\
\hline \multicolumn{9}{|l|}{ Sons } \\
\hline Mother gender role attitudes $<0.5$ & 0.060 & $(0.150)$ & -0.044 & $(0.105)$ & 0.015 & $(0.167)$ & -0.093 & $(0.126)$ \\
\hline Mother gender role attitudes $>0.5$ & 0.050 & $(0.060)$ & 0.033 & $(0.039)$ & 0.014 & $(0.065)$ & -0.034 & $(0.049)$ \\
\hline Mother employed < 30 hours pw & -0.007 & $(0.018)$ & 0.000 & $(0.012)$ & 0.006 & $(0.019)$ & 0.012 & $(0.015)$ \\
\hline Mother employed $\geq 30$ hours pw & $-0.074^{* * *}$ & $(0.028)$ & 0.016 & $(0.021)$ & -0.033 & $(0.033)$ & 0.006 & $(0.026)$ \\
\hline Cognitive test score & $-0.567^{* * * *}$ & $(0.057)$ & $0.322^{* * *}$ & $(0.038)$ & $-0.528^{* * * *}$ & $(0.062)$ & $0.502^{* * * *}$ & $(0.048)$ \\
\hline Behaviour/emotion problems & $0.234^{* * *}$ & $(0.063)$ & -0.066 & $(0.045)$ & $0.178^{* *}$ & $(0.070)$ & $-0.162^{* * *}$ & $(0.057)$ \\
\hline Mother years of education & $-0.067^{* * *}$ & $(0.008)$ & $0.019^{* * *}$ & $(0.003)$ & $-0.066^{* * *}$ & $(0.007)$ & $0.026^{* * * *}$ & $(0.004)$ \\
\hline Mother liberal parent & $-0.206^{* * *}$ & $(0.058)$ & $0.087^{* *}$ & $(0.037)$ & 0.024 & $(0.063)$ & $0.159^{* * *}$ & $(0.046)$ \\
\hline Father social class: unskilled & $0.184^{* * *}$ & $(0.047)$ & $-0.073^{* * *}$ & $(0.018)$ & $0.151^{* * *}$ & $(0.046)$ & $-0.095^{* * *}$ & $(0.028)$ \\
\hline Sample size & 4185 & & 4185 & & 4185 & & 4185 & \\
\hline
\end{tabular}

Notes: Figures are marginal effect estimates calculated at mean covariate values. All models include covariates displayed in Tables 2 and 3 plus year and region effects. Robust absolute standard errors are presented in parentheses. *, ** and *** signify statistical significance at $0.10,0.05$ and 0.01 levels. Linear effect of mothers' gender role attitudes differs for values below and above 0.5. Expectations outcomes measured in 1980. Whether the cohort member attained a degree-level qualification is recorded in year 2004 (age 34). 
Table 5:

Random-Effect Probit and Tobit Models of Daughter Labour Supply 2000-2008

\begin{tabular}{|c|c|c|c|c|c|c|c|c|}
\hline & \multicolumn{4}{|c|}{ Full-Time Employment Probit Models } & \multicolumn{4}{|c|}{ Weekly Work Hours Tobit Models } \\
\hline & $\begin{array}{l}\mathrm{ME} \\
(\mathrm{se})\end{array}$ & $\begin{array}{l}\mathrm{ME} \\
(\mathrm{se})\end{array}$ & $\begin{array}{l}\mathrm{ME} \\
(\mathrm{se})\end{array}$ & $\begin{array}{l}\mathrm{ME} \\
(\mathrm{se})\end{array}$ & $\begin{array}{c}\beta \\
(\mathrm{se})\end{array}$ & $\begin{array}{c}\beta \\
(\mathrm{se})\end{array}$ & $\begin{array}{c}\beta \\
(\mathrm{se})\end{array}$ & $\begin{array}{c}\beta \\
(\mathrm{se})\end{array}$ \\
\hline Mother gender role attitudes & $\begin{array}{l}0.287^{\text {**** }} \\
(0.068)\end{array}$ & $\begin{array}{c}0.277^{* * * *} \\
(0.068)\end{array}$ & $\begin{array}{l}0.263^{\text {***** }} \\
(0.067)\end{array}$ & $\begin{array}{l}0.258^{\text {***** }} \\
(0.072)\end{array}$ & $\begin{array}{l}7.132^{\text {**** }} \\
(1.765)\end{array}$ & $\begin{array}{l}6.952^{\text {**** }} \\
(1.762)\end{array}$ & $\begin{array}{l}6.620^{\text {***** }} \\
(1.728)\end{array}$ & $\begin{array}{l}5.382^{* * *} \\
(1.521)\end{array}$ \\
\hline Mother employed $<30$ hours pw & $\begin{array}{c}0.042 \\
(0.026)\end{array}$ & $\begin{array}{l}0.043^{*} \\
(0.026)\end{array}$ & $\begin{array}{c}0.049^{*} \\
(0.026)\end{array}$ & $\begin{array}{l}0.064^{* *} \\
(0.028)\end{array}$ & $\begin{array}{l}1.998^{* * * *} \\
(0.682)\end{array}$ & $\begin{array}{c}2.032^{* * * *} \\
(0.680)\end{array}$ & $\begin{array}{c}2.136^{* * * *} \\
(0.667)\end{array}$ & $\begin{array}{c}2.234^{\text {**** }} \\
(0.587)\end{array}$ \\
\hline Mother employed $\geq 30$ hours pw & $\begin{array}{c}0.082^{*} \\
(0.045)\end{array}$ & $\begin{array}{c}0.076^{*} \\
(0.045)\end{array}$ & $\begin{array}{c}0.084^{*} \\
(0.044)\end{array}$ & $\begin{array}{l}0.135^{* * *} \\
(0.046)\end{array}$ & $\begin{array}{l}2.594^{* *} \\
(1.150)\end{array}$ & $\begin{array}{l}2.418^{* *} \\
(1.147)\end{array}$ & $\begin{array}{l}2.586^{* *} \\
(1.125)\end{array}$ & $\begin{array}{l}3.272^{* * *} \\
(0.990)\end{array}$ \\
\hline Expected to leave school at 16 & & $\begin{array}{c}-0.098^{\text {**** }} \\
(0.026)\end{array}$ & $\begin{array}{l}-0.057^{* *} \\
(0.026)\end{array}$ & $\begin{array}{c}-0.092^{* * * *} \\
(0.028)\end{array}$ & & $\begin{array}{c}-3.113^{* * *} \\
(0.688)\end{array}$ & $\begin{array}{c}-1.967^{\text {**** }} \\
(0.683)\end{array}$ & $\begin{array}{c}-2.237^{* * *} \\
(0.602)\end{array}$ \\
\hline Expected to attend university & & $\begin{array}{c}0.098^{* * *} \\
(0.034)\end{array}$ & $\begin{array}{c}0.048 \\
(0.034)\end{array}$ & $\begin{array}{c}0.054 \\
(0.037)\end{array}$ & & $\begin{array}{c}1.350 \\
(0.880)\end{array}$ & $\begin{array}{c}0.003 \\
(0.870)\end{array}$ & $\begin{array}{l}-0.172 \\
(0.765)\end{array}$ \\
\hline Left school at 16 & & & $\begin{array}{c}-0.091^{* * * *} \\
(0.025)\end{array}$ & $\begin{array}{l}-0.050^{*} \\
(0.027)\end{array}$ & & & $\begin{array}{c}-2.166^{* * *} \\
(0.665)\end{array}$ & $\begin{array}{l}-1.064^{*} \\
(0.585)\end{array}$ \\
\hline Attained a degree & & & $\begin{array}{l}0.303^{* * *} \\
(0.029)\end{array}$ & $\begin{array}{c}0.182^{* * * *} \\
(0.033)\end{array}$ & & & $\begin{array}{l}8.628^{* * *} \\
(0.795)\end{array}$ & $\begin{array}{l}4.725^{* * *} \\
(0.703)\end{array}$ \\
\hline Married & & & & $\begin{array}{c}-0.089^{* * * * * 3} \\
(0.021)\end{array}$ & & & & $\begin{array}{l}-0.587 \\
(0.432)\end{array}$ \\
\hline Child & & & & $\begin{array}{c}-0.823^{* * *} \\
(0.012)\end{array}$ & & & & $\begin{array}{c}-22.084^{* * * *} \\
(0.481)\end{array}$ \\
\hline Sample size & 11628 & 11628 & 11628 & 11628 & 11377 & 11377 & 11377 & 11377 \\
\hline
\end{tabular}

Notes: Figures from employment models are marginal effect estimates calculated at mean covariate values. Figures from Tobit models are coefficient estimates. All models include covariates displayed in Tables 2 and 3 plus year and region effects. Robust standard errors are presented in parentheses. *, ** and *** signify statistical significance at 0.10, 0.05 and 0.01 levels. Labour supply outcome variables measured in 2000, 2004 and 2008. Whether the cohort member attained a degree-level qualification is recorded in year 2004 (age 34) 
Table 6:

Fixed-Effect Models of Daughter Labour Supply with Mother Gender Role Interaction Effects

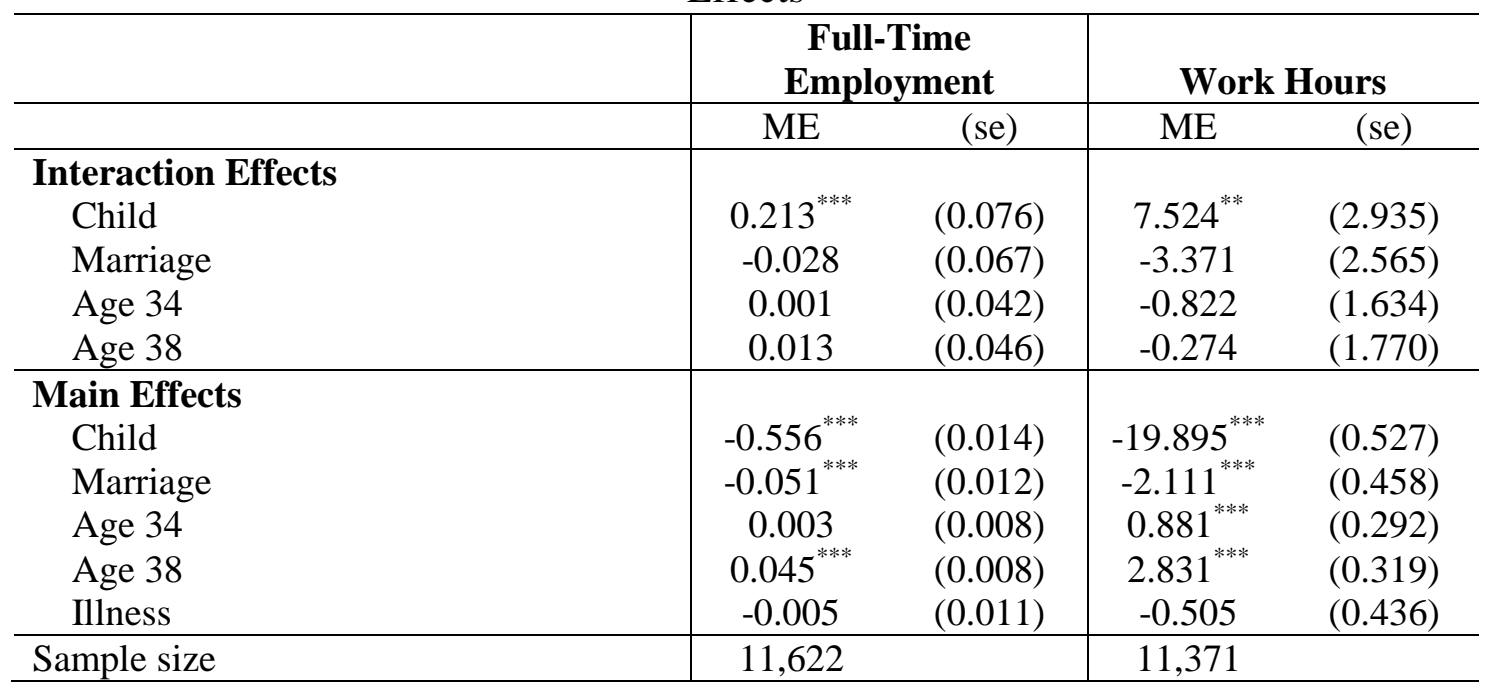

Notes: Selected coefficient estimates shown. Standard errors are presented in parentheses. *, ** and *** signify statistical significance at 0.10, 0.05 and 0.01 levels. Full-time employment measured in 2000, 2004 and 2008. 
Appendix Table A1: Maternal Attitude Questions from 1975 British Cohort Study Survey

\begin{tabular}{|c|c|c|c|c|c|}
\hline & $\begin{array}{l}\text { Strongly } \\
\text { Disagree }\end{array}$ & $\begin{array}{c}\text { Mildly } \\
\text { Disagree }\end{array}$ & $\begin{array}{l}\text { Cannot } \\
\text { Say }\end{array}$ & $\begin{array}{l}\text { Mildly } \\
\text { Agree }\end{array}$ & $\begin{array}{l}\text { Strongly } \\
\text { Agree }\end{array}$ \\
\hline $\begin{array}{l}\text { 1. Women need something more from life than they can get by } \\
\text { just looking after the home and children }\end{array}$ & 3.12 & 5.30 & 3.72 & 39.88 & 47.97 \\
\hline $\begin{array}{l}\text { 2. Girls should accept the fact that they will marry and have } \\
\text { children and not think about starting a career }\end{array}$ & 73.74 & 14.60 & 2.80 & 4.15 & 4.71 \\
\hline 3. Women should have the same work opportunities as men & 5.75 & 8.19 & 4.18 & 25.88 & 56.00 \\
\hline $\begin{array}{l}\text { 4. There is nothing wrong with a mother going out to work if her } \\
\text { children can be properly cared for by someone else. }\end{array}$ & 10.59 & 13.29 & 4.87 & 34.73 & 36.52 \\
\hline $\begin{array}{l}\text { 5. A mother who leaves her children with someone else in order } \\
\text { to go out to work is no fit to be a mother unless she needs the } \\
\text { money for food and clothes }\end{array}$ & 35.88 & 23.08 & 12.42 & 15.97 & 12.65 \\
\hline $\begin{array}{l}\text { 6. A wife must sacrifice her right to go out to work once she has } \\
\text { children }\end{array}$ & 32.35 & 26.27 & 6.12 & 20.09 & 15.17 \\
\hline 7. A mother's proper place is at home with her children & 9.10 & 18.43 & 6.27 & 32.80 & 33.39 \\
\hline
\end{tabular}

Appendix Table A2: Cohort Child Attitude Questions from 2000 British Cohort Study Survey

\begin{tabular}{|c|c|c|c|c|c|c|}
\hline & & $\begin{array}{l}\text { Strongly } \\
\text { Disagree }\end{array}$ & Disagree & Neither & Agree & $\begin{array}{l}\text { Strongly } \\
\text { Agree }\end{array}$ \\
\hline & $\begin{array}{l}\text { A pre-school child is likely to suffer if his or her mother } \\
\text { works }\end{array}$ & 10.35 & 41.22 & 25.85 & 18.93 & 3.65 \\
\hline & $\begin{array}{l}\text { All in all, family life suffers when the mother has a full time } \\
\text { job }\end{array}$ & 7.46 & 39.99 & 31.07 & 17.52 & 3.96 \\
\hline & Children benefit if their mother has a job outside the home & 1.35 & 14.67 & 57.77 & 22.70 & 3.51 \\
\hline & $\begin{array}{l}\text { A mother and her family will all be happier if she goes out to } \\
\text { work }\end{array}$ & 3.99 & 31.62 & 55.32 & 7.72 & 1.34 \\
\hline & $\begin{array}{l}\text { A father's job is to earn money; a mother's job is to look after } \\
\text { the home and family }\end{array}$ & 26.63 & 45.62 & 18.60 & 6.82 & 2.34 \\
\hline
\end{tabular}


Appendix Table A3:

Sample Means of Outcome Variable and Main Covariates

\begin{tabular}{|c|c|c|c|}
\hline & All & Daughters & Sons \\
\hline \multicolumn{4}{|l|}{ Outcome Measures } \\
\hline Gender role attitudes (2000) & 0.568 & 0.586 & 0.549 \\
\hline Full-time employed (2000-2008) & 0.670 & 0.460 & 0.904 \\
\hline Work hours per week (2000-2008) & 33.064 & 24.669 & 42.450 \\
\hline Work hours per week if employed (2000-2008) & 39.734 & 32.695 & 46.196 \\
\hline Expected to leave school at $16(1980)$ & 0.334 & 0.316 & 0.353 \\
\hline Expected to attend university (1980) & 0.155 & 0.152 & 0.158 \\
\hline Left school at 16 & 0.418 & 0.374 & 0.467 \\
\hline Attained university degree (2004) & 0.222 & 0.217 & 0.227 \\
\hline Married or cohabitating (2000) & 0.680 & 0.714 & 0.641 \\
\hline Own child in household (2000) & 0.451 & 0.538 & 0.359 \\
\hline \multicolumn{4}{|l|}{ Covariates (1975) } \\
\hline Mother gender role attitudes & 0.676 & 0.681 & 0.672 \\
\hline Mother employed $<30$ hours per week & 0.300 & 0.300 & 0.300 \\
\hline Mother employed $\geq 30$ hours per week & 0.080 & 0.079 & 0.081 \\
\hline Number of younger sisters & 0.249 & 0.251 & 0.247 \\
\hline Number of older sisters & 0.483 & 0.491 & 0.474 \\
\hline Number of younger brothers & 0.266 & 0.274 & 0.257 \\
\hline Number of older brothers & 0.516 & 0.494 & 0.542 \\
\hline Cognitive test score & 0.540 & 0.540 & 0.541 \\
\hline Behavioural/emotional problems & 0.200 & 0.194 & 0.206 \\
\hline Number of medical conditions & 0.751 & 0.698 & 0.811 \\
\hline Low birth weight & 0.056 & 0.057 & 0.054 \\
\hline Mother age at birth & 26.069 & 26.052 & 26.088 \\
\hline Mother smoked during pregnancy & 0.385 & 0.381 & 0.389 \\
\hline Mother years of post-compulsory education & 0.892 & 0.865 & 0.923 \\
\hline Mother liberal parenting beliefs & 0.447 & 0.444 & 0.450 \\
\hline Mother single & 0.051 & 0.055 & 0.048 \\
\hline Father age at birth & 28.826 & 28.808 & 28.846 \\
\hline Father years of post-compulsory education & 1.187 & 1.178 & 1.197 \\
\hline Father employed & 0.914 & 0.918 & 0.910 \\
\hline Father SC: non-manual skilled & 0.097 & 0.096 & 0.099 \\
\hline Father SC: manual skilled & 0.451 & 0.450 & 0.451 \\
\hline Father SC: semi-skilled & 0.120 & 0.126 & 0.114 \\
\hline Father SC: unskilled & 0.039 & 0.039 & 0.039 \\
\hline Neighbourhood: poor & 0.058 & 0.061 & 0.056 \\
\hline Neighbourhood: well-to do & 0.257 & 0.255 & 0.259 \\
\hline Neighbourhood: rural & 0.210 & 0.209 & 0.212 \\
\hline Religion: Church of England & 0.395 & 0.423 & 0.363 \\
\hline Religion: Catholic & 0.106 & 0.114 & 0.097 \\
\hline Religion: other-Christian & 0.229 & 0.240 & 0.217 \\
\hline Religion: other non-Christian & 0.019 & 0.020 & 0.018 \\
\hline
\end{tabular}

Note: Statistics calculated with 4,468 mother-daughter pairs and 4,222 mother-son pairs. 